\title{
PEMANFAATAN E-APPLICATION DALAM PENINGKATAN PROSES AUDIT MUTU INTERNAL (STUDI KASUS : UNIVERSITAS BINA NUSANTARA)
}

\author{
Cuk Tho; Wihendro; Yohannes Kurniawan \\ Jurusan Teknik Informatika, Fakultas Ilmu Komputer, Universitas Bina Nusantara \\ Jln K.H. Syahdan No.9 Palmerah Jakarta Barat 11480 \\ cuktho@binus.edu ${ }^{1}$, wihendro@binus.edu ${ }^{2}$, ykurniawan@binus.edu ${ }^{3}$
}

\begin{abstract}
This paper shows the use of e-application to assist the implementation of internal quality audit, which is one of the conditions to be met within the requirements of ISO 9000 Quality Assurance System. E-application that is used other than as a data repository is also used as a workflow. Where is the workflow that is made will ensure that the repairs is carried out in accordance with what has been planned. As one of the ISO documentation requirements in Clause 4.2.4 that a document should be done traceable, then the use of eapplication is very helpful in conducting the search trail. In addition, the e-application allows auditors and auditees in filling the audit results, since it can be accessed from anywhere as well as due to web-based, it can be done from any computer without the need of an installation. E-application that was developed to function as a workflow and data repository that can be used as part of monitoring and data history which will help to improve the performance of the unit hence also improves performance of Bina Nusantara University.
\end{abstract}

Keywords: ISO 9000, internal quality audit, website, e-application

\begin{abstract}
ABSTRAK
Paper ini menampilkan tulisan mengenai penggunaan e-application untuk membantu pelaksanaan audit mutu internal, yang merupakan salah satu syarat yang harus dipenuhi dalam persyaratan Sistem Penjaminan Mutu ISO 9000. E-application yang digunakan selain sebagai data repository juga digunakan sebagai workflow. Dimana workflow yang dibuat akan memastikan bahwa perbaikan dijalankan sesuai dengan yang telah direncanakan. Sebagai salah satu persyaratan dokumentasi ISO dalam Klausul 4.2.4(p.3 ) bahwa sebuah dokumen harus dapat dilakukan telusur jejak, maka penggunaan e-application ini sangat membantu dalam melakukan telusur jejak. Selain itu, e-application memudahkan auditor dan auditee dalam mengisi hasil audit, dikarenakan dapat diakses dari manapun serta dikarenakan berbasis web, maka dapat dilakukan dari computer mana saja tanpa harus dilakukan instalasi terlebih dahulu. e-application yang dikembangkan ini berfungsi sebagai workflow dan data repository sehingga dapat digunakan sebagai bagian dari monitoring dan data history yang ada akan sangat membantu untuk memperbaiki kinerja unit tersebut terlebih kinerja universitas Bina Nusantara.
\end{abstract}

Kata kunci:ISO 9000, Audit Mutu Internal, situs web, e-application. 


\section{PENDAHULUAN}

Mutu merupakan aspek yang penting bagi Universitas Bina Nusantara, oleh karenanya Sistem Manajemen Mutu ISO 9000 dipilih sejak tahun 1997 sebagai salah satu tools untuk menjaga dan meningkatkan mutu pendidikan dari Universitas Bina Nusantara. Sebagaimana diketahui, ISO 9001 dalam klausul 8.2.2 (ISO, 2008) mensyaratkan adanya pelaksanaan audit mutu internal, dan disinergikan dengan klausul 4.2.4 (ISO, 2008) dimana record yang didapatkan dari hasil audit mutu internal harus disimpan, mudah diambil , dan dapat dilakukan telusur jejak. Disamping itu pula, setiap hasil audit mutu internal, apabila ditemukan ketidaksesuain maka harus dilakukan tindakan perbaikan dan pencegahan, yang hasilnya juga harus sesuai dengan persyaratan ISO 9001 klausul 4.2.4 (ISO, 2008) serta tindakan perbaikan dan pencegahan yang telah dilakukan harus diverifikasi.

Pada awal implementasi ISO 9000, dokumentasi dilakukan secara manual, tetapi seiring berkembangnya Universitas Bina Nusantara, maka dokumentasi manual sangat sulit dilakukan mengingat banyaknya kertas yang harus didistribusikan, pencatatan dan adanya kemungkinan hilangnya berkas tersebut. Untuk mengatasi hal tersebut, maka aplikasi Lotus Notes digunakan baik sebagai workflow maupun sebagai data repository. Namun demikian, keterbatasan aplikasi Lotus Notes adalah harus dilakukan instalasi terlebih dahulu, dan hanya dapat dilakukan apabila terhubung dengan LAN. Selain itu juga, user hanya dapat mengakses pada komputernya masing - masing, dikarenakan user_id_hanya tersedia dikomputer masing - masing. Untuk mengatasi hal tersebut, maka dikembangkan e-application yang dapat digunakan dari computer mana pun, selama terhubung dengan internet. E-application yang selanjutnya dinamakan aplikasi Audit Mutu Internal sangat membantu user yang berperan sebagai auditor, maupun auditee, termasuk juga unit Quality Management System yang bertanggung jawab atas pelaksanaan audit mutu internal di Universitas Bina Nusantara.

\section{Tahapan Pengembangan}

Aplikasi berbasis web merupakan sebuah aplikasi yang kesemuanya ataupun sebagian dari software didownload dari web setiap kali aplikasi tersebut dijalankan . Apabila berdasarkan akses, terdapat 3 jenis aplikasi web (Wall \& Lader, 2002) yaitu internet, intranet dan extranet. Aplikasi web dengan menggunakan internet, dapat diakses dari mana saja selama user terhubung dengan internet. Adapun dalam pengembangan aplikasi audit mutu internal ini, yang digunakan adalah Visual Studio 2008 (ASP.Net) sebagai software untuk pengembangan website, dan SQL Server 2000 digunakan sebagai database.

Selain itu pula, aplikasi audit mutu internal ini juga mengakses aplikasi dan database lainnya yang telah di kembangkan sebelumnya yaitu HRIS (Human Resource Information System). Akses ini diperlukan untuk menarik data user yaitu berupa data struktur organisasi, dan jabatan. Hal ini digunakan untuk menentukan hak akses dari masing masing user. Sesuai standar ISO 19011: 2002 (ISO, 2002) , definisi audit adalah proses yang sistematik, independen, dan terdokumentasi untuk mendapatkan bukti audit dan mengevaluasi secara objektif untuk menentukan kriteria audit. Definisi untuk auditee adalah organisasi yang diaudit, dan auditor adalah orang yang mempunyai kompetensi untuk melakukan audit.

Perancangan aplikasi audit mutu internal terbagi dalam beberapa tahap menurut Britton dan Doake (2005), yaitu :

- Requirements : pada tahapan ini dilakukan pengumpulan informasi yang dibutuhkan, baik dari sistem yang telah berjalan sebelumnya, penetapan hak akses bagi setiap user berdasarkan dari struktur organisasi yang sudah ada, penetapan ruang lingkup, dan persyaratan ISO 9000 yang harus dipenuhi. Pada tahapan ini pula, alur proses diperbaiki sehingga lebih efektif. 
- Analysis : Tahapan ini, dimana hasil dari requirement capture dikembangkan, dan dibuat sebuah model sederhana dari sudut pandang user. Berdasarkan model sederhana yang disetujui maka langkah selanjutnya dikerjakan

- Design : pada tahapan inilah, aplikasi dibuat dengan penuh. Aplikasi yang dikembangkan terdiri dari front - end dan back-end. Front-end, akan menampilkan user sebagai auditee dan auditor, sedangkan back-end, akan digunakan oleh unit Quality Management Center

- Implementation : ditahap ini, aplikasi yang dibuat telah dilakukan testing lengkap..

- Instalation : tahap implementasi adalah tahap dimana aplikasi digunakan, dan sebelumnya dilakukan training penggunaan aplikasi untuk user baik yang bertindak sebagai auditee maupun sebagai auditor.

Sebagaimana disampaikan sebelumnya, aplikasi ini selain berfungsi sebagai data repository, juga berfungsi sebagai aplikasi workflow. Alur workflow dapat dilihat pada gambar berikut ini :

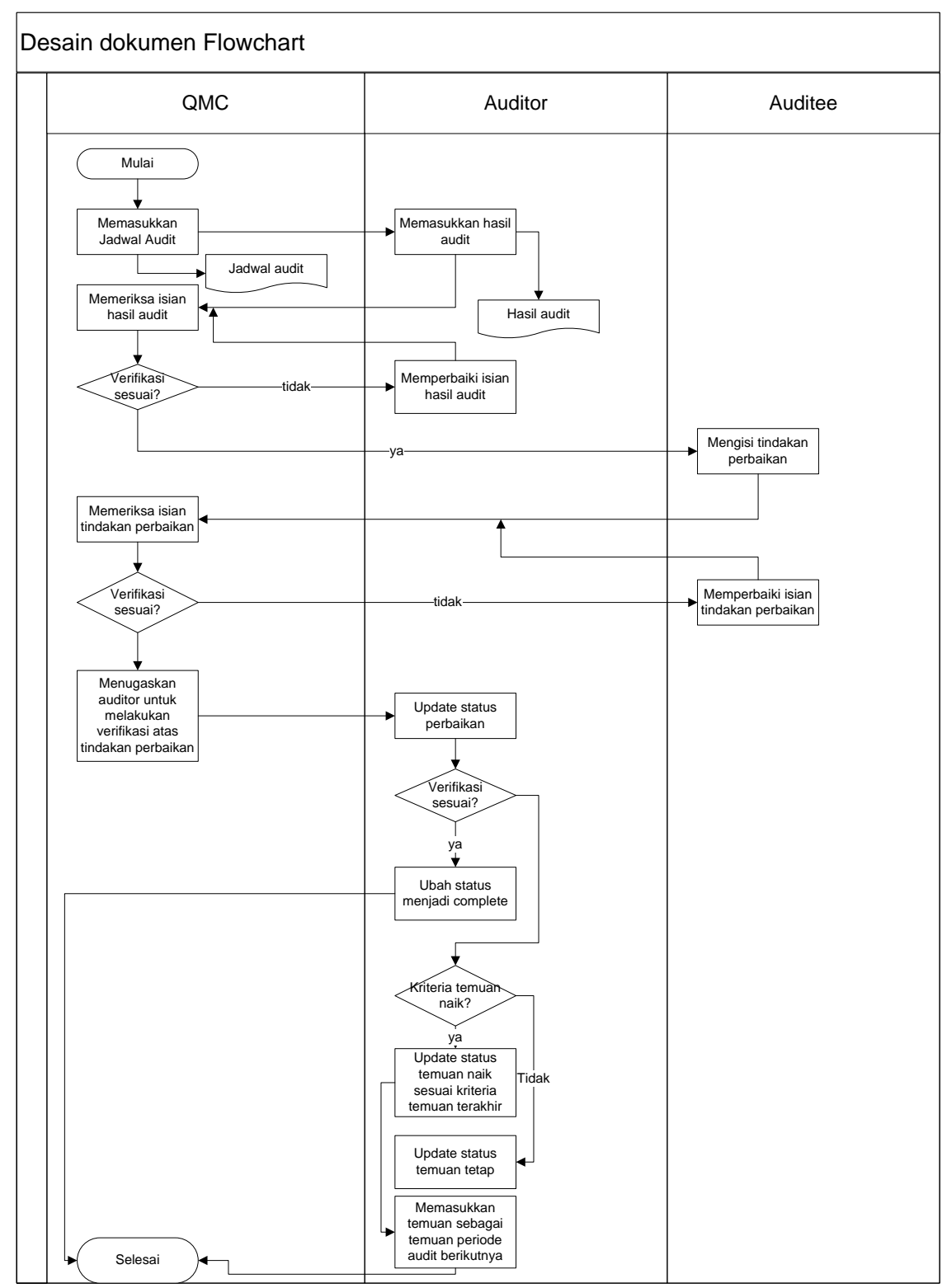

Gambar 1 : Desain Dokumen Flowchart 


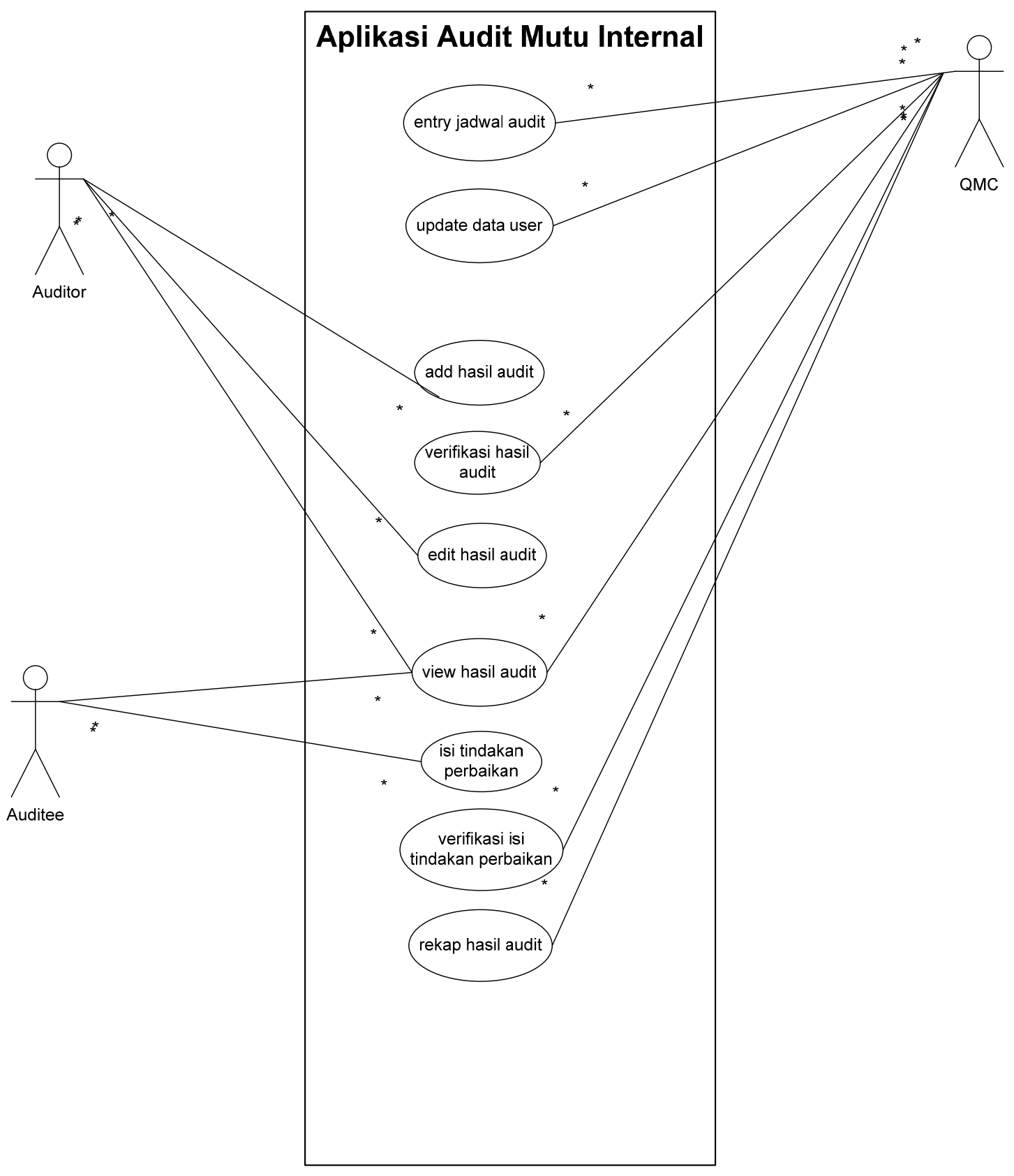

Gambar 2 : Use Case Diagram

Berikut ini adalah rancangan database yang digunakan untuk aplikasi audit mutu internal dan workflow audit mutu internal. 


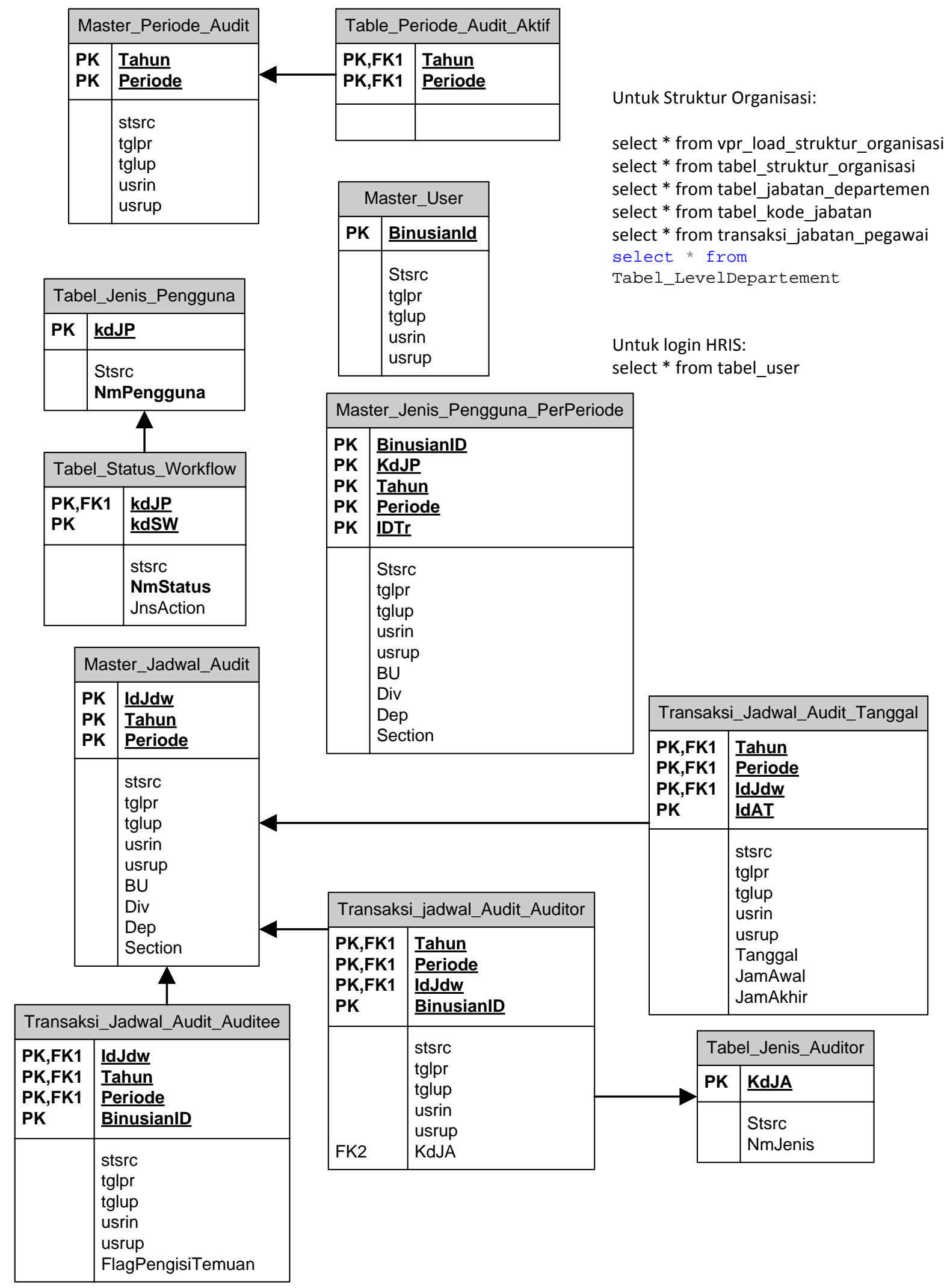

Gambar 3 : ERD Diagram database Aplikasi Audit Mutu Internal 


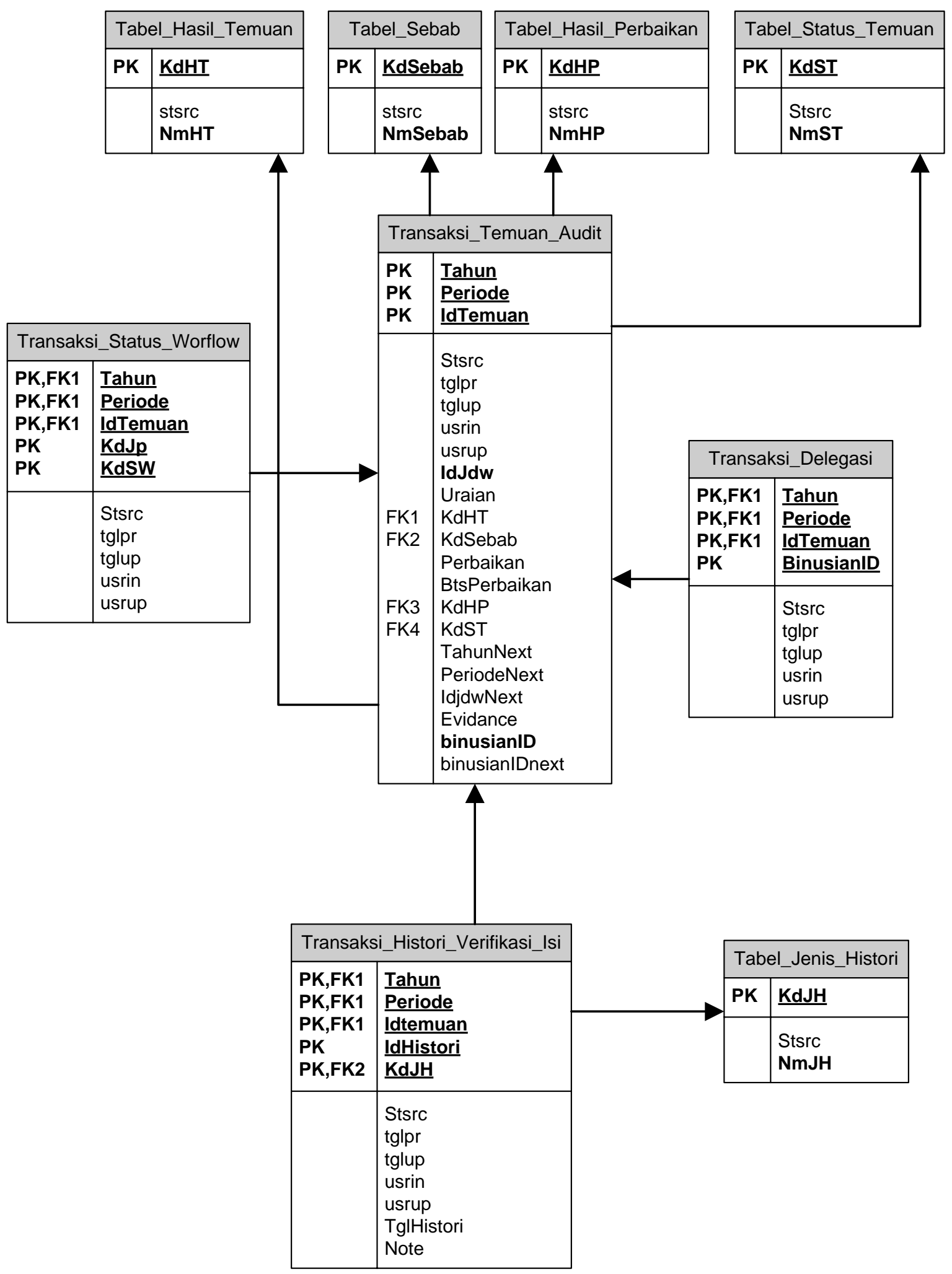

Gambar 4 : ERD Diagram Workflow Audit Mutu Internal 


\section{HASIL DAN PEMBAHASAN}

\section{Implementasi Aplikasi Audit Mutu Internal}

Aplikasi Audit Mutu Internal ini terdiri dari dua bagian yaitu Front End dan Back End. Frontend diperuntukan bagi user yang berstatus sebagai auditee maupun sebagai auditor, sedangkan backend diperuntukkan bagi Quality Management Center.

Untuk login ke dalam aplikasi audit mutu internal ini, maka diperlukan username dan password, yang telah disesuaikan dengan username dan password dari HRIS yang sebelumnya sudah di implementasikan oleh bagian Talent Management. Dengan demikian, user tidak perlu mengingat banyak username dan password.

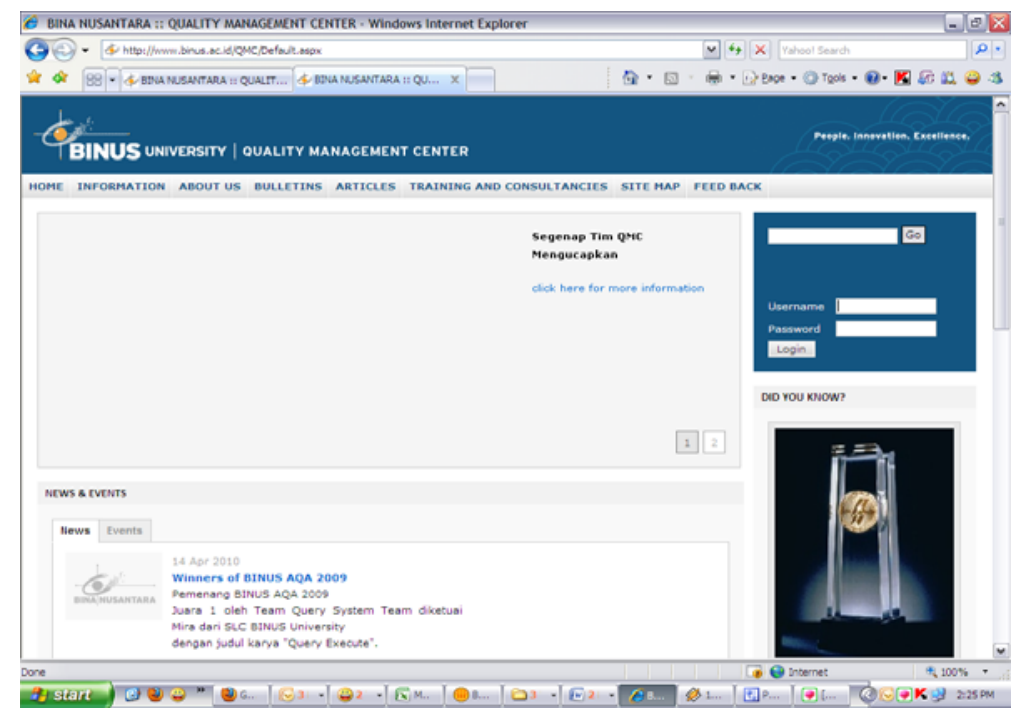

Gambar 5: Tampilan login aplikasi AMI

\section{Front End}

Pada bagian front end ini terdiri dari menu Jadwal Audit dan Workflow, dimana kedua menu ini mencakup user sebagai auditor maupun sebagai auditee. Apabila user hanya sebagai auditee saja, maka yang akan muncul hanya menu auditee, begitu juga sebaliknya. Sedangkan jika user berfungsi sebagai auditee dan auditor, maka keduanya akan ditampilkan pada menu tersebut.

Penjelasan setiap menu yang ada, adalah sebagai berikut ini

- Menu Jadwal Audit : berisi jadwal audit baik dalam bentuk summary maupun detail, Adapun detail jadwal audit terdiri dari Unit yang akan diaudit, baik apabila user sebagai auditee maupun sebagai auditor. Adapun untuk detail jadwal yang ditampilkan berupa nama business unit / direktorat, divisi, unit sampai dengan sub unit, nama - nama auditor dari lead auditor dan auditor pendamping, tanggal dan waktu pelaksanaan audit.

- Menu Workflow : terdiri dari dua sub menu yaitu sebagai auditee dan sebagai auditor. Untuk auditor, maka workflow ini digunakan untuk mengisi hasil temuan, memperbaiki pengisian hasil temuan, verifikasi atas hasil audit periode sebelumnya, 
dan melihat history hasil audit periode - periode sebelumnya. Apabila user sebagai auditee, maka workflow ini akan digunakan untuk pengisian tindakan perbaikan dan pencegahan, perbaikan pengisian tindakan perbaikan dan pencegahan, melihat status tindakan perbaikan dan pencegahan, melihat history audit periode - periode sebelumnya.

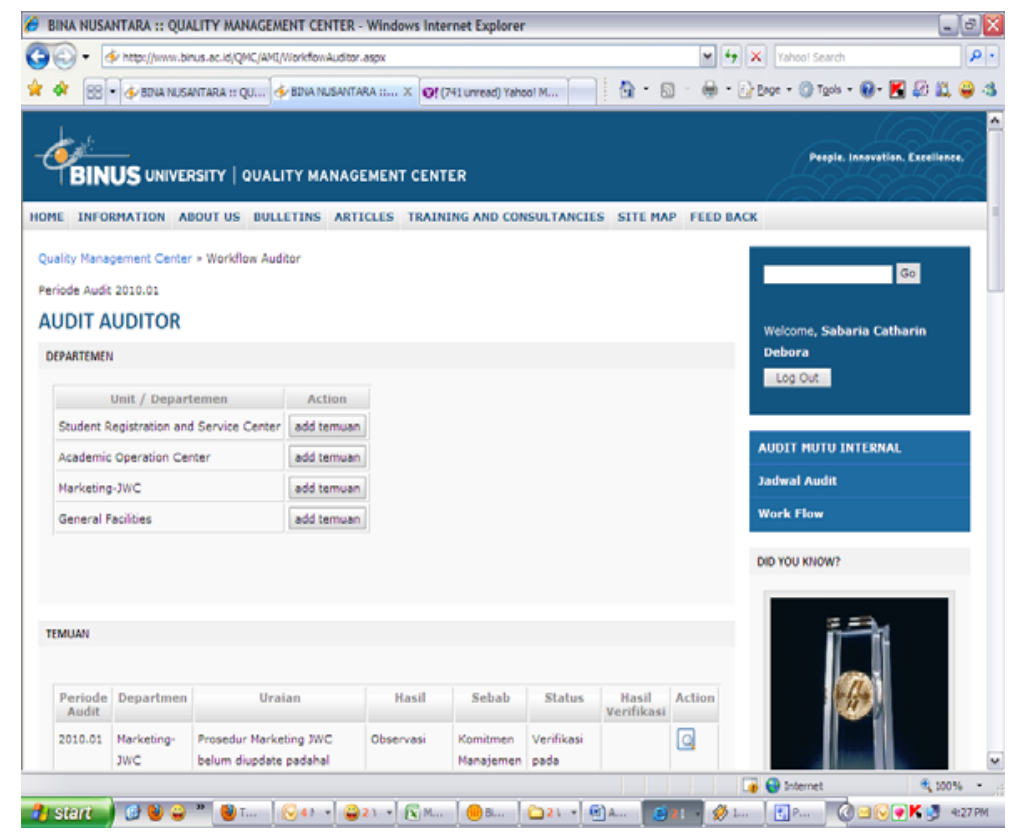

Gambar 6 : Tampilan add temuan

\section{Back End}

Back - end hanya dapat digunakan oleh Quality Management Center, dimana pada back end ini terdiri dari menu :

- Audit Period : akan diisi dengan periode audit, dimana 01 adalah ganjil, dan 02 adalah genap

- Auditor / Auditee Registration : menu ini akan mengassign siapa saja yang menjadi auditor dan yang menjadi auditee

- $\quad$ Audit Scheduling

o Audit List : akan diisi dengan unit mana saja yang akan diaudit

o Entry Schedule : akan di isi dengan jadwal audit yang telah disepakati, termasuk auditor dan unit yang akan diaudit.

- Workflow audit and Monitor workflow : workflow baru dapat digunakan apabila schedule telah dibuat. Dimana pada menu ini, QMC akan melakukan verifikasi terhadap isi temuan, isi perbaikan, dan hasil tindakan perbaikan yang telah dilakukan. Selain itu juga dapat dilakukan monitoring terhadap pelaksanaan audit. Selain itu dapat pula dilihat rekapitulasi dari hasil audit yang telah di masukan oleh auditor.

Berikut adalah tampilan back end aplikasi AMI untuk QMC yaitu menu untuk memilih periode audit, auditee/auditor registration, audit scheduling dan workflow AMI. 


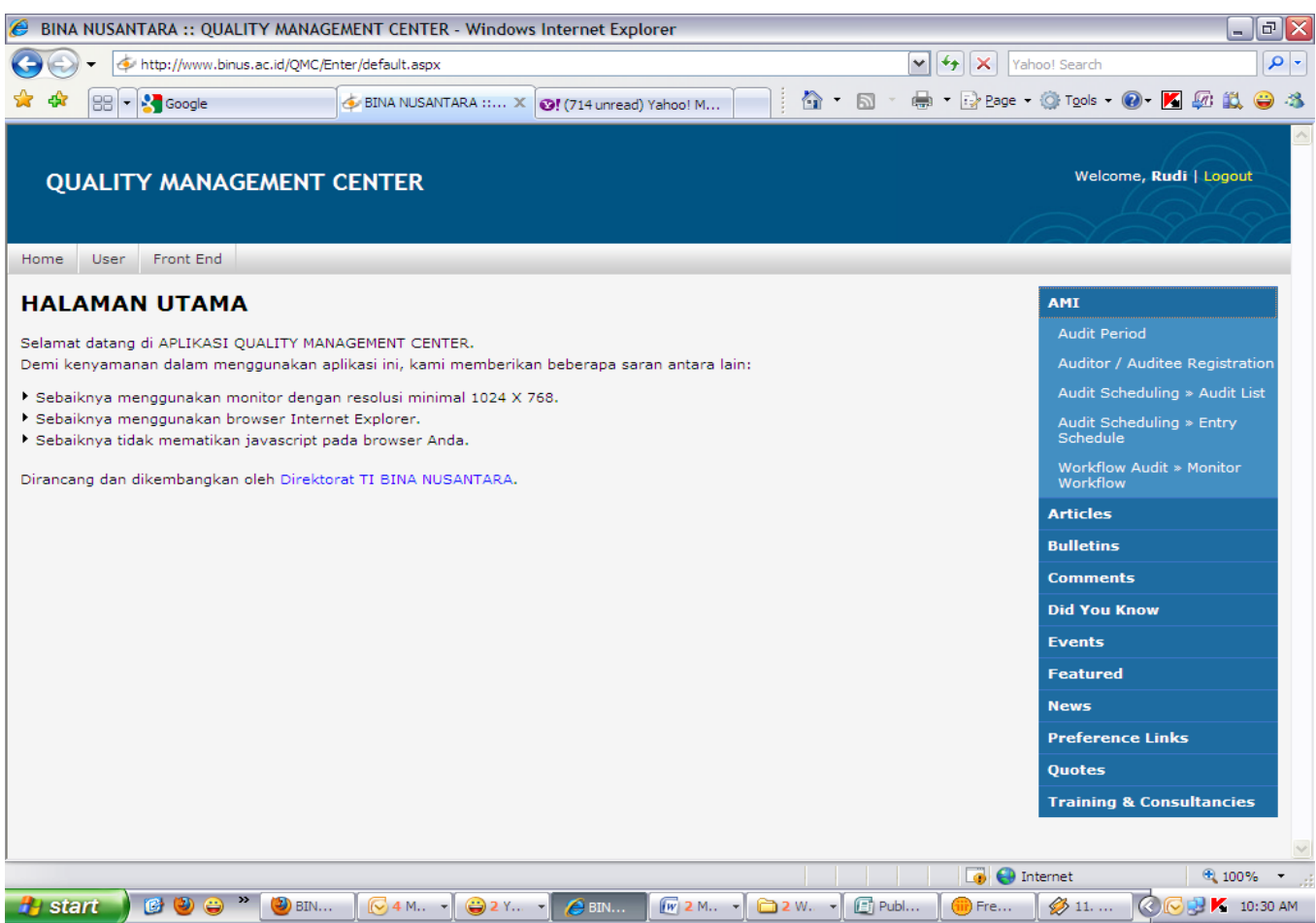

Gambar 7 : Tampilan halaman utama back-end

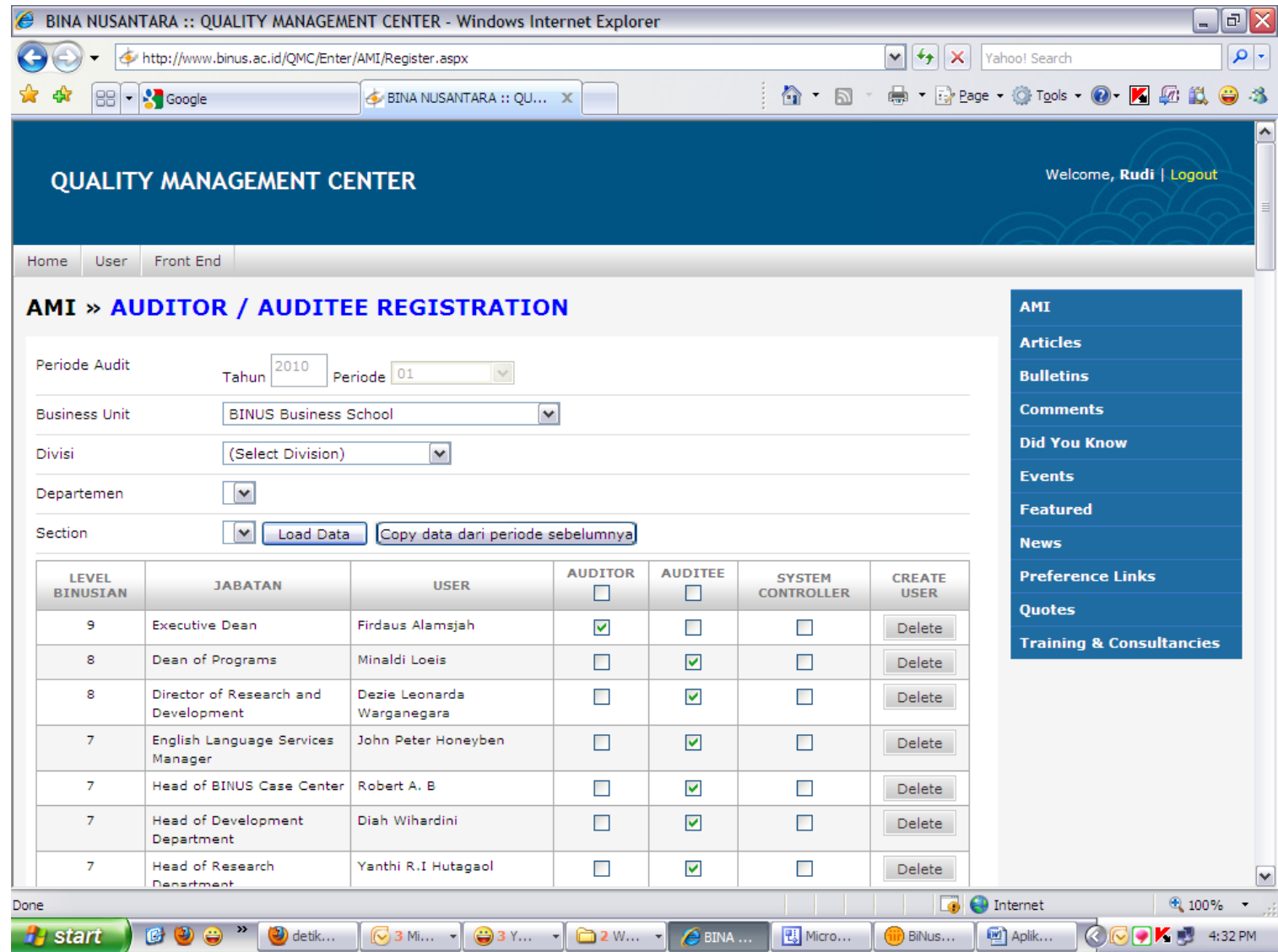

Gambar 8 : Tampilan Registrasi Auditee dan Auditor 


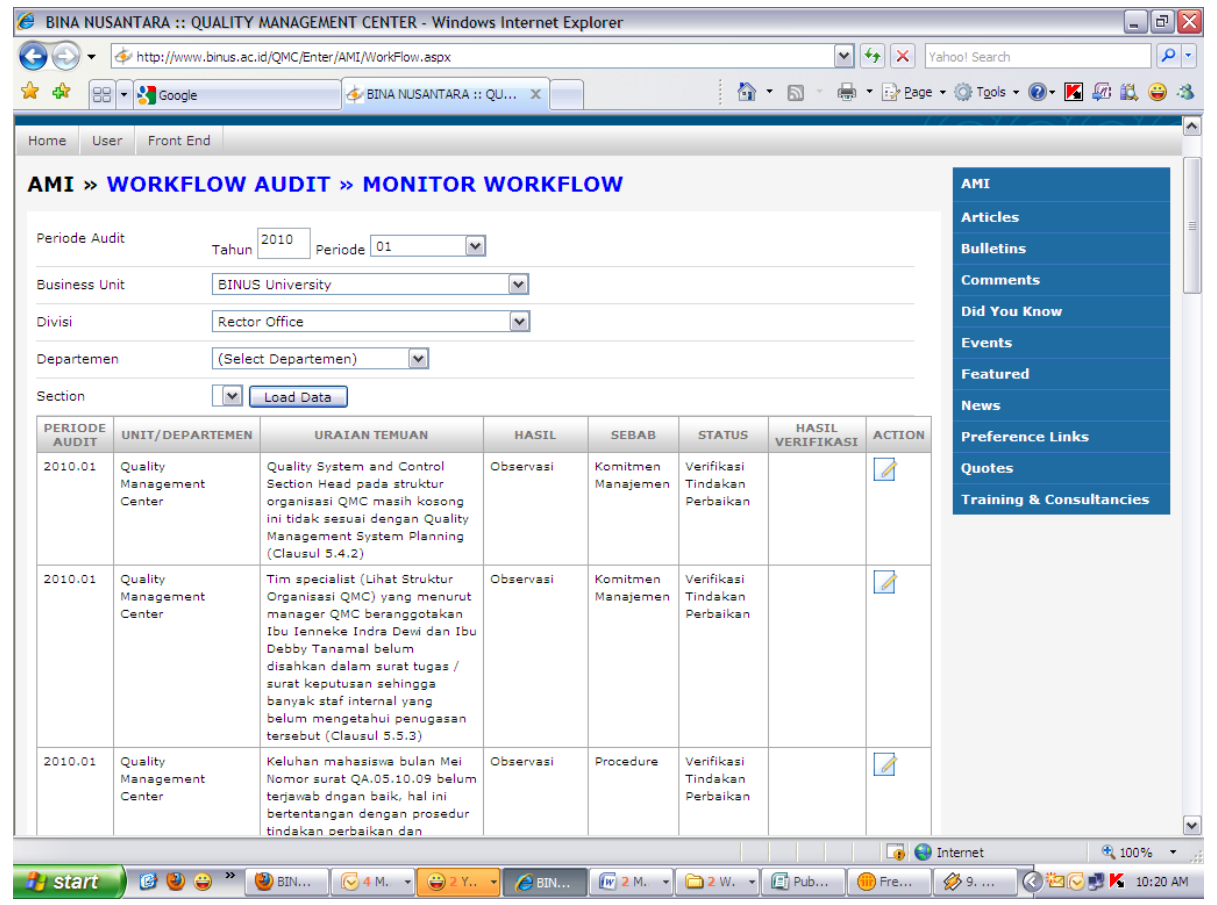

Gambar 9 : Tampilan Monitoring workflow

\section{SIMPULAN}

Aplikasi Audit Mutu Internal ini memberikan kemudahan bagi auditee, auditor, dan unit Quality Management Center dalam melakukan pendataan, monitoring dan penyimpanan data. Dengan penggunaan e-application, maka data yang ada dapat diakses dari manapun ditempat user berada, tanpa harus melakukan instalasi aplikasi dan dapat digunakan secara mobile, sehingga proses audit mutu internal dapat dilaksanakan dengan baik. Selain itu, auditee maupun auditor dapat melihat data history yang dapat digunakan untuk perbaikan proses yang ada dan peningkatan kompetensi dalam melakukan audit. Diharapkan pengembangan aplikasi audit mutu internal ini juga dapat disatukan dengan aplikasi lainnya yang sudah ada, sehingga hanya diperlukan satu login untuk semua aplikasi yang ada di Universitas Bina Nusantara.

\section{DAFTAR PUSTAKA}

International Organization for Standardization, (2008). ISO 9001:2008 , Quality Management System - Requirements.

International Organization for Standardization, (2002). ISO 19011:2002, Guidelines for Quality and / or environmental Management Systems Auditing

Britton, C. and Doake, J. (2005). A Student Guide to Object Oriented Development., Elsevier Butterworth - Heinemann.

Wall, L., and Lader, A., (2002). Building Web Services and .Net Applications, McGraw Hill. 